\title{
Co-occurring PTPN1 1 and SOS1 gene mutations in Noonan syndrome: does this predict a more severe phenotype?
}

\author{
Coocorrência de mutações nos genes PTPN1 1 e SOS1 na síndrome \\ de Noonan: este achado prediz um fenótipo mais grave?
}

Amanda Salem Brasil', Alexsandra C. Malaquias², Luciana Turolla Wanderley', Chong Ae Kim', José Eduardo Krieger ${ }^{3}$, Alexander A. L. Jorge ${ }^{4}$, Alexandre C. Pereira ${ }^{3}$, Débora Romeo Bertola' ${ }^{1}$

\section{SUMMARY}

Noonan syndrome (NS) is an autosomal dominant disorder, with variable phenotypic expression, characterized by short stature, facial dysmorphisms and heart disease. Different genes of the RAS/MAPK signaling pathway are responsible for the syndrome, the most common are: PTPN11, SOS1, RAF1, and KRAS. The objective of this study was to report a patient with Noonan syndrome presenting mutations in two genes of RAS/MAPK pathway in order to establish whether these mutations lead to a more severe expression of the phenotype. We used direct sequencing of the PTPN11, SOS1, RAF1, and KRAS genes. We have identified two described mutations in heterozygosity: p.N308D and p.R552G in the genes PTPN11 and SOS1, respectively. The patient has typical clinical features similar to the ones with NS and mutation in only one gene, even those with the same mutation identified in this patient. A more severe or atypical phenotype was not observed, suggesting that these mutations do not exhibit an additive effect. Arq Bras Endocrinol Metab. 2010;54(8):717-22

\section{SUMÁRIO}

A síndrome de Noonan (SN) é uma doença gênica autossômica dominante, com expressão clínica variável, caracterizada por baixa estatura, dismorfismos faciais e cardiopatia. Diferentes genes da via de sinalização RAS/MAPK são responsáveis pela síndrome, sendo as mais frequentes: PTPN11, SOS1, RAF1 e KRAS. O objetivo deste estudo foi relatar um paciente com SN que apresenta mutações em dois genes da via RAS/MAPK a fim de estabelecer se essas mutações levam a uma expressão mais grave do fenótipo. Utilizou-se sequenciamento direto dos genes PTPN11, SOS1, RAF1 e KRAS. Foram identificadas duas mutações em heterozigose previamente descritas: p.N308D e p.R552G nos genes PTPN11 e SOS1, respectivamente. A paciente apresenta quadro clínico típico semelhante ao dos pacientes com SN e mutação em um único gene, mesmo naqueles com a mesma mutação identificada na paciente. Não foi observado um fenótipo mais grave ou atípico na paciente, sugerindo que as mutações não apresentam um efeito aditivo. Arq Bras Endocrinol Metab. 2010;54(8):717-22

\section{INTRODUCTION}

$\mathrm{N}^{\circ}$ oonan syndrome (NS; OMIM 163950) is an autosomal dominant disorder with an estimated incidence between $1 / 1,000$ and $1 / 2,500$ (1). The
${ }^{1}$ Genetics Unit, Children's Institute, Hospital das Clínicas, Faculdade de Medicina, Universidade de São Paulo, Sao Paulo, SP, Brazil ${ }^{2}$ Endocrinology of Development Unit, Hormone and Molecular Genetics Laboratory, LIM/42, HC-FMUSP, Sao Paulo, SP, Brazil ${ }^{3}$ Laboratory of Genetics and Molecular Cardiology, Heart's Institute (InCor), HC-FMUSP, Sao Paulo, SP, Brazil

${ }^{4}$ Endocrinology-Genetics Unit LIM/25, Discipline of Endocrinology, HC-FMUSP, Sao Paulo, SP, Brazil
Correspondence to: Amanda Salem Brasil Unidade de Genética, Instituto da Criança,HC-FMUSP Av. Dr. Enéas de Carvalho Aguiar, 647 05403-900 - São Paulo, SP, Brazil amandasb@usp.br debora.bertola@icr.usp.br

Received on Aug/2/2010 Accepted on Nov/15/2010 main clinical features, which are extremely variable, include short stature, facial dysmorphisms, webbed neck, cardiac abnormalities (especially pulmonary stenosis and hypertrophic cardiomyopathy) and cryptorchidism in the males [Reviewed in ref. (2)]. 
The molecular background was recently unveiled. Different genes of the RAS/MAPK signaling pathway are responsible for NS (Table 1) (3-11). Mutation in the PTPN11, SOS1, RAFI and KRAS genes, usually leading to a gain-of-function, is found in approximately $70 \%$ of NS (12) cases. Mutations in other genes in this pathway are rarely described in NS patients, including $B R A F, M E K 1, M E K 2, S H O C 2$ and $C B L(12,13)$.

Due to the complexity of the molecular analysis in NS, previous studies have screened patients initially for the PTPNIl gene, the main gene in the syndrome. Only in those patients who were negative for mutations in this gene, were the other genes subsequently analyzed until a mutation was found.

Several hormones, including growth hormone (GH) (2) and insulin-like growth factor I (IGF-1), act through receptors that stimulate the RAS/MAPK pathway, and therefore, NS and related disorders represent a remarkable opportunity to study the implication of the RAS/MAPK pathway in different endocrine systems. Additionally, children with NS are frequently referred to endocrinologists because of short stature, delayed puberty and/or undescended testes in males. Therefore, NS is important in the differential diagnosis of short stature and has important implications in GH therapy.

Recently, two groups described NS patients presenting two mutations in different RAS/MAPK pathway-related genes $(14,15)$. In both studies, one of the mutations predicted to affect the protein function (pathogenic mutation), while the other mutation predicted to be benign (uncertain pathogenicity).

To evaluate if the variable expressivity in this syndrome is due partially to the presence of more than one mutation in genes of the RAS/MAPK pathway, we screened a cohort of NS syndrome patients for the main responsible genes - PTPNII, SOS1, RAFI and KRAS. Herein, we report on a single patient presenting two pathogenic mutations in the main genes responsible for NS - PTPNII and SOSI.

Table 1. Major genes of RAS/MAPK signaling pathway involved with Noonan syndrome

\begin{tabular}{lccc}
\hline Locus & Mutation Gene & (\%) & Reference \\
\hline $12 q 24.1$ & PTPN11 & $29-70$ & $(4,12)$ \\
$2 p 22.1$ & $S O S 1$ & $17^{\mathrm{a}}-28^{\mathrm{a}}$ & $(9,11)$ \\
$3 \mathrm{p} 25.1$ & RAF1 & $9^{\mathrm{b}}-17^{\mathrm{b}}$ & $(6,7)$ \\
$12 \mathrm{p} 12.1$ & KRAS & $2^{\mathrm{a}}-6^{\mathrm{b}}$ & $(3,5)$ \\
\hline
\end{tabular}

a) In patients without PTPN11 gene mutation; b) In patients without PTPN11 and SOS1 genes mutation.

\section{CASE REPORT}

The proband, a 10 year-old female, is the only child of non-consanguineous parents. Her mother was 22 years old and her father 36 years old at the time of conception, both parents had normal height (mother's height $=158 \mathrm{~cm}$ and father's height $=183 \mathrm{~cm}$ ). She was born at term, by vaginal delivery, with a birth weight of $2,710 \mathrm{~g}$ (-1.3 SDS) and length of $48 \mathrm{~cm}(-0.5 \mathrm{SDS})$. A heart murmur was audible and a diagnosis of pulmonary stenosis was disclosed. She was first evaluated at our cardiology clinic and a cardiac surgery was indicated at the age of 3 years and 3 months due to the presence of valvar and supravalvar pulmonary stenosis and ostium secundum atrial septal defect (ASD) on the echocardiogram. EKG showed signs of right ventricular hypertrophy. At the first evaluation she was $89 \mathrm{~cm}$ tall (height SDS = -1.8), weighed 11,100 g (body mass index SDS = -1.5) and her head circumference was $47.2 \mathrm{~cm}$ (-1.5 SDS). She had Noonan syndrome-related dysmorphisms (Figure 1): mild hypertelorism, left ptosis, slight proptosis, malocclusion, high arched palate, overfolded pinnae; webbed neck; sternal deformity (pectus carinatum superiorly and excavatum inferiorly); hepatoesplenomegaly and distal joints hiperextensibility. No evident ectodermal findings were disclosed. She had normal developmental milestones. Complementary exams showed normal abdominal ultrasound, spine $\mathrm{X}$-ray, bone age, hematological studies, including factor $\mathrm{XI}$ analysis and karyotype. Ophthalmologic evaluation demonstrated prominent corneal nerves on slit-lamp exam. At the age of 10 years, she is enrolled at a regular school, without major difficulties. A positive family history of NS was not uncovered, either by the physical exam of the mother or by medical history and photographs of the father.

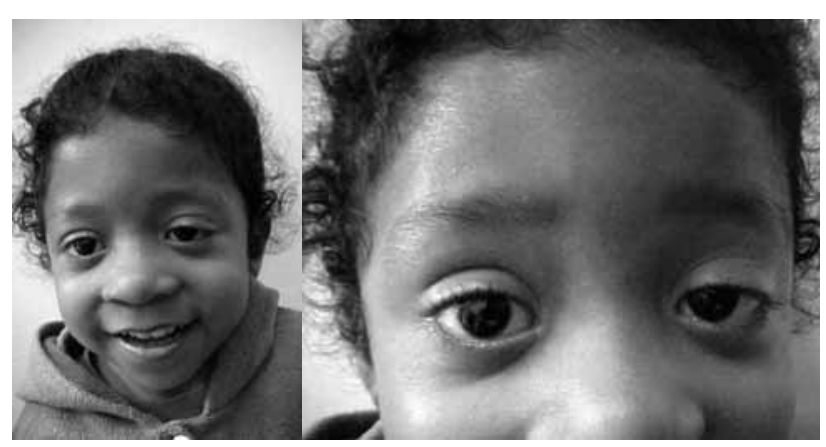

Figure 1. Noonan syndrome patient showing typical NS facial dysmorphisms: hypertelorism, left ptosis and slight proptosis. 


\section{SUBJECTS AND METHODS}

\section{Molecular studies}

This patient was included in an on-going cohort study of NS, approved by the Institutional Ethics Committee of Hospital das Clínicas da Faculdade de Medicina de São Paulo (HC-FMUSP). Briefly, venous blood was drawn for genomic DNA extraction from peripheral leukocytes using a salting-out protocol.

PTPN11 exons 2-15 (Reference sequence: NC_000012.11), SOS1 exons 1-23 (NC_000002.11), RAFI exons 7, 14, and 17 (NC_000003.11) and KRAS exons 2-6 (NC_000012.11) were amplified using specific intronic primers (primer sequences and amplification protocols will be sent upon request). PCR products from these exons were directly sequenced with dideoxy chain-termination method using a kit ABI PrismTM BigDye Terminator (Perkin Elmer, Foster City, CA, USA) and analyzed by an autosequencer ABI Prism Genetic Analyser 3100 automatic DNA sequencer (Perkin Elmer). Genotype sequences were manually observed using DNASTAR SeqMan - Laser Gene. New allelic variants identified in SOSI were also investigated in 192 control individuals (384 alleles).

\section{In silico prediction of mutation effects}

Missense variants identified by sequencing were classified based on their potential impact on protein function or structure, using a new version of the PolyPhen method (16). These predictions are based on the analysis of multiple sequence alignments of homologous proteins, functional annotation and structural information. PolyPhen defines the predictions of the mutations as follows: 1) probably damaging: it is with high confidence that it is supposed to affect protein function or structure, 2) possibly damaging: it is supposed to affect protein function or structure and 3 ) benign: it is most likely that it lacks any phenotypic effect.

Another investigation of the variations identified in this study include a tool for whole genome compara- tive analysis of the human genome using the VISTA Genome Browser (17). Multiple amino acid alignments were built using wild-type and mutated human sequence and wild-type Fugu rubripes, Pan troglodytes, Gallus gallus, Xenopus tropicalis, Canis familiaris, Danio rerio and Trichoplax adbaerens sequences.

\section{Laboratory evaluation}

GH and insulin were measured by an immunofluorometric assay (AutoDELFIA ${ }^{\circledR}$, PerkinElmer, Waltham, MA, USA). Cut-off levels used to rule out GH deficiency diagnosis after stimulation test were peak GH levels > $3.3 \mu \mathrm{g} / \mathrm{L}$ : (18). IGF-1 and IGFBP-3 were measured by chemiluminescence assays (IMMULITE, Diagnostic Products Corporation - DPC, Los Angeles, CA, USA) and expressed as SDS for age and sex according to reference values provided by the assay kit.

\section{RESULTS}

\section{Molecular results}

Positive molecular findings are summarized in table 2 . No mutation was identified in the KRAS and RAFI genes. One previously described mutation in PTPNII was identified in the heterozygous state [p.N308S (14)]. Direct sequencing of SOSI revealed two heterozygous allelic variants: one previously described mutation [p.R552G (9)] and a new variant p.A708T. For the two previously described mutations, the alterations are predicted to be probably damaging and amino acid residues are conserved between different species. On the other hand, the new alteration found (p.A708T in the SOS1 gene), is predicted to be benign and is not conserved among species. Furthermore, a control group was screened and this specific gene alteration was present in 4 out of 192 control individuals in the heterozygous state (allelic frequency of 1\%), characterizing a polymorphism in our population. The patient's mother had none of these three described allelic variants. Unfortunately, DNA from the father was not available.

Table 2. Summary of the mutations found in the presently described Noonan syndrome patient

\begin{tabular}{lcccccc}
\hline Gene & Exon & Nucleotide & Amino Acid & Described & PolyPhen & $\begin{array}{c}\text { VISTA } \\
\text { Genome Browser }\end{array}$ \\
\hline PTPN11 & 8 & c.A1121G & p.N308S & Yes $^{\mathrm{a}}$ & Probably damaging & Conserved \\
SOS1 & 10 & c.A1654G & p.R552G & Yes $^{\mathrm{b}}$ & Probably damaging & Conserved \\
SOS1 & 13 & c.G2122A & p.A708T & No & Benign & No conserved \\
\hline
\end{tabular}

a) Literature for p.N308S in PTPN11 gene (10,19-23); b) Literature for p.R552G in SOS1 gene (9,11,24-26); PolyPhen (16); VISTA Genome Browser (17). 


\section{Phenotype analysis}

The present patient, who has co-occurring mutations in the PTPNII and SOS1 genes, did not have a more severe phenotype than those NS patients with mutations only in PTPN11 or SOS1. In our group we identified five other NS patients with p.N308S mutation in the PTPN11 gene and one patient with p.R552G mutation in the SOSI gene (14,27). The phenotype of these patients did not significantly differ from the patient harboring both mutations (Table 3).

Table 3. Clinical phenotype of NS patient with co-occurrence of PTPN11 (p.N308D) and SOS1 (p.R552G) pathogenic mutations in comparison with NS patients with only one of the genes.

\begin{tabular}{|c|c|c|c|}
\hline Mutation(s) & $\begin{array}{c}\text { p.N308S } \\
\text { (PTPN11) and } \\
\text { p.R552G } \\
\text { (S0S1) }\end{array}$ & $\begin{array}{l}\text { p.N308S } \\
\text { (PTPN11) }\end{array}$ & $\begin{array}{r}\text { p.R552G } \\
\text { (SOS1) }\end{array}$ \\
\hline Patient(s) & 1 & 5 & 1 \\
\hline Typical facial features & + & $5 / 5$ & + \\
\hline Pulmonary stenosis & + & $2 / 5$ & - \\
\hline Sternal deformity & + & $3 / 5$ & + \\
\hline Development delay & - & $2 / 5$ & - \\
\hline Height SDSa & -1.8 & -1.2 to -3.9 & -1.5 \\
\hline Height SDS ${ }^{b}$ & 0.2 & -2.1 to +1.2 & 0.4 \\
\hline BMI SDS & -1.5 & -1.0 to 0.1 & 1.3 \\
\hline
\end{tabular}

Height SDS was calculated using age- and gender-specific norms (a) for general population (28) and (b) specific for Noonan syndrome patients (29).

\section{Hormonal analysis}

Patient had normal metabolic evaluation for her age: fasting glucose and insulin were $77 \mathrm{mg} / \mathrm{dL}(4.2$ $\mathrm{mmol} / \mathrm{L}$ ) and $<2.5 \mu \mathrm{U} / \mathrm{mL}$, respectively. She also had an unremarkable lipid profile (Total cholesterol of 136 $\mathrm{mg} / \mathrm{dL}$, HDS-cholesterol of $40 \mathrm{mg} / \mathrm{dL}$ and triglycerides of $98 \mathrm{mg} / \mathrm{dL}$ ). IGF-1 and IGFBP-3 levels were at the lower normal range for sex and age $(61 \mu \mathrm{g} / \mathrm{L}$ and $2.0 \mu \mathrm{g} / \mathrm{mL}$, respectively; both corresponding to -1.7 SDS). During the clonidine test to evaluate GH secretion, the patient had a GH peak of $8.5 \mu \mathrm{g} / \mathrm{L}$, ruling out $\mathrm{GH}$ deficiency. These hormonal findings were similar to the ones observed in other NS patients in our group (30).

\section{DISCUSSION}

In the present study we described a NS patient with simultaneous pathogenic mutations in two of the most common genes associated with NS - PTPNII and SOS1. The patient has typical features of NS - short stature, classic facial features, webbed neck and the specific heart defect (pulmonary stenosis associated with atrial septal defect).

Missense heterozygous mutations in the PTPN11 gene are found in approximately $50 \%$ of NS patients (19), clustered especially in exons 3,8 , and 13. Different from exons 3 and 13 , in which the mutations are spread, mutations in exon 8 mainly involve residue 308. Indeed, the most frequent mutation found in NS is p.N308D $(10,19)$. Mutation p.N308S has also been found in several studied patients (10,19-23).

Regarding the SOS1 gene, two gene alterations were found in our patient. The p.R552G is a known pathogenic mutation, the most frequent one in this gene associated with NS $(9,11,24-26)$. Concerning the novel p.A708T, additional analysis (in silico analysis and a control group test) showed that this gene alteration is a polymorphism in our population and most probably is not associated to significant phenotypic effects.

Although a clear genotype-phenotype correlation in NS has not been established, patients presenting mutations in PTPNII tend to show a higher prevalence of pulmonary stenosis, short stature, sternal deformity and bleeding diathesis $(10,19)$. Specifically for the mutation p.N308D, Tartaglia and cols. (19) demonstrated that the patients required less special education, compared to other described mutations in PTPNII gene. For the SOSI gene, patients presenting mutations in this gene showed more ptosis, ectodermal signs, such as keratosis pilaris and curly hair, and normal intelligence (11). Roberts and cols. (25) showed that their patients also had a high frequency of pulmonary stenosis, but ASD was relatively rare. On the other hand, Tartaglia and cols. (9) found less short stature in their patients.

The proband here presented does not show atypical findings or a more severe phenotype than NS patients with isolate mutations - even when compared to patients with p.N308S or pR552G mutations in PTPNII and SOS1, respectively. Some of the features presented by our patient are common to mutations in both genes, such as the typical facial features and the cardiac lesion - valvar pulmonary stenosis. On the other hand, the proband showed short stature, ASD and lack of evident ectodermal findings, which is more consistent with the phenotype of patients harboring mutations in the PTPN11 gene (9-11,19,25).

The genes here involved (PTPNII and SOS1), coding for upstream proteins of the RAS/MAPK signaling pathway, are closely connected to SHC and GRB2 
proteins. All these proteins belong to the same complex that has the function of exchanging GDP for GTP to activate the RAS-RAF-MEK-ERK cascade. Mutations in PTPNII and SOS1 reported here, commonly lead to a gain-of-function of the RAS/MAPK pathway. The fact that we did not observe a more severe phenotype in our patient with mutations in both genes suggests that mutations in these two genes do not have additive effects, leading to a typical NS phenotype.

The occurrence of two known pathogenic mutations in genes of the RAS/MAPK pathway in NS has not been described before. Two previous studies $(14,15)$, including one from our group, showed the presence of one known pathogenic mutation and another gene alteration that probably functions as a modifier. We described a NS patient presenting the pathogenic p.N308D mutation in the PTPN11 gene and also the p.N85S mutation in the KRAS gene (14). The patient presented typical features of NS and learning disabilities, which is not common, but far from an exception, in individuals with the p.N308D mutation in the PTPN11 gene. Ekvall and cols. (15) reported on a NS patient presenting mild psychomotor developmental delay, hoarse voice, osteoporosis, loose anagen hair, gingival hyperplasia, spinal neuroblastoma and liver haemangioma, and mutations in the SHOC2 gene (p.S2G) and PTPN11 gene (p.G409A). The mother, presenting only short stature, also showed this latter gene alteration. The authors concluded that the p.G409A mutation in the PTPNII gene represents a mild partial mutation, acting as a modifier. On the other hand, the report of two pathogenic mutations in patients presenting neurofibromatosis-Noonan syndrome (NFNS) have been previously described $(31,32)$ but in both cases one of the parents had one of the mutations, which increases the chance of this occurrence.

The rate of new mutations is very low in general and the presence of two mutations in our case is out of the ordinary. Unfortunately, we were not able to rule out with certainty that the father comprised one of these mutations, but photographs failed to show any facial features suggestive of NS. Besides, there is no history of heart problems and he has a height of I SD above the mean.

The great variability in the phenotype of NS patient still remains to be properly elucidated. The presence of two different pathogenic mutations in our patient, which is an extremely rare event, failed to show an important effect in the phenotype. We can speculate that subtler gene alterations, such as polymorphisms of single nucleotides (SNPs) in genes of this pathway or even other genes associated with environmental factors may modulate the phenotype.

Acknowledgments: this work was supported by grants from Fundacao de Amparo à Pesquisa do Estado de São Paulo (FAPESP) (08/50184-2 and 07/59555-0 to A.C.M.) and from National Council for Scientific and Technological Development (CNPq) (301477/2009-4 to A.A.L.J.). The authors thank Noely Ferreira for technical support.

Disclosure: no potential conflict of interest relevant to this article was reported.

\section{REFERENCES}

1. Nora JJ, Nora AH, Sinha AK, Spangler RD, Lubs HA. The UIIrich-Noonan syndrome (Turner phenotype). Am J Dis Child. 1974;127(1):48-55.

2. Malaquias AC, Ferreira LV, Souza SC, Arnhold IJ, Mendonca BB, Jorge AA. [Noonan syndrome: from phenotype to growth hormone therapy]. Arq Bras Endocrinol Metabol. 2008;52(5):800-8.

3. Carta C, Pantaleoni F, Bocchinfuso G, Stella L, Vasta I, Sarkozy A, et al. Germline missense mutations affecting KRAS Isoform $B$ are associated with a severe Noonan syndrome phenotype. Am J Hum Genet. 2006;79(1):129-35.

4. Musante L, Kehl HG, Majewski F, Meinecke P, Schweiger S, Gillessen-Kaesbach G, et al. Spectrum of mutations in PTPN11 and genotype-phenotype correlation in 96 patients with Noonan syndrome and five patients with cardio-facio-cutaneous syndrome. Eur J Hum Genet. 2003;11(2):201-6.

5. Nava C, Hanna N, Michot C, Pereira S, Pouvreau N, Niihori T, et al. Cardio-facio-cutaneous and Noonan syndromes due to mutations in the RAS/MAPK signalling pathway: genotype-phenotype relationships and overlap with Costello syndrome. J Med Genet. 2007;44(12):763-71.

6. Pandit B, Sarkozy A, Pennacchio LA, Carta C, Oishi K, Martinelli S, et al. Gain-of-function RAF1 mutations cause Noonan and LEOPARD syndromes with hypertrophic cardiomyopathy. Nat Genet. 2007;39(8):1007-12.

7. Razzaque MA, NishizawaT, KomoikeY, Yagi H, Furutani M, Amo R, et al. Germline gain-of-function mutations in RAF1 cause Noonan syndrome. Nat Genet. 2007;39(8):1013-7.

8. Sarkozy A, Carta C, Moretti S, Zampino G, Digilio MC, Pantaleoni $\mathrm{F}$, et al. Germline BRAF mutations in Noonan, LEOPARD, and cardiofaciocutaneous syndromes: molecular diversity and associated phenotypic spectrum. Hum Mutat. 2009;30(4):695-702.

9. Tartaglia M, Pennacchio LA, Zhao C, Yadav KK, Fodale V, Sarkozy A, et al. Gain-of-function SOS1 mutations cause a distinctive form of Noonan syndrome. Nat Genet. 2007;39(1):75-9.

10. Zenker M, Buheitel G, Rauch R, Koenig R, Bosse K, Kress W, et al. Genotype-phenotype correlations in Noonan syndrome. J Pediatr. 2004;144(3):368-74.

11. Zenker M, Horn D, Wieczorek D, Allanson J, Pauli S, van der Burgt $\mathrm{I}$, et al. SOS1 is the second most common Noonan gene but plays no major role in cardio-facio-cutaneous syndrome. J Med Genet. 2007;44(10):651-6.

12. Tartaglia M, Zampino G, Gelb BD. Noonan syndrome: clinical aspects and molecular pathogenesis. Mol Syndromol. 2010;1(1):2-26. 
13. Martinelli S, De Luca A, Stellacci E, Rossi C, Checquolo S, Lepri F, et al. Heterozygous Germline Mutations in the CBL tumor-suppressor gene cause a Noonan syndrome-like phenotype. Am J Hum Genet. 2010;87(2):250-7.

14. Brasil AS, Pereira AC, Wanderley LT, Kim CA, Malaquias AC, Jorge AA, et al. PTPN11 and KRAS gene analysis in patients with Noonan and Noonan-like syndromes. GenetTest Mol Biomarkers. 2010;14(3):425-32.

15. Ekvall $S$, Hagenäs $L$, Annerén G, Bondeson M. Identification of co-occurring SHOC2 and PTPN11 mutations in a patient with Noonan syndrome. Eur J Hum Genet. 2010;18(1):90-1.

16. Ramensky V, Bork P, Sunyaev $S$. Human non-synonymous SNPs: server and survey. Nucleic Acids Res. 2002;30(17):3894-900.

17. Frazer KA, Pachter L, Poliakov A, Rubin EM, Dubchak I. VISTA: computational tools for comparative genomics. Nucleic Acids Res. 2004;32(Web Server issue):W273-9.

18. Silva EG, Slhessarenko N, Arnhold IJ, Batista MC, Estefan V, Osorio $M G$, et al. $\mathrm{GH}$ values after clonidine stimulation measured by immunofluorometric assay in normal prepubertal children and GH-deficient patients. Horm Res. 2003;59(5):229-33.

19. Tartaglia M, Kalidas K, Shaw A, Song X, Musat DL, van der Burgt I, et al. PTPN11 mutations in Noonan syndrome: molecular spectrum, genotype-phenotype correlation, and phenotypic heterogeneity. Am J Hum Genet. 2002;70(6):1555-63.

20. Ko JM, Kim JM, Kim GH, Yoo HW. PTPN11, SOS1, KRAS, and RAF1 gene analysis, and genotype-phenotype correlation in Korean patients with Noonan syndrome. J Hum Genet. 2008;53(1112):999-1006.

21. Bertola DR. Estudo do gene PTPN11 nos pacientes afetados pela síndrome de Noonan. São Paulo: Faculdade de Medicina da Universidade de São Paulo; 2006.

22. Binder G, Neuer K, Ranke MB, Wittekindt NE. PTPN11 mutations are associated with mild growth hormone resistance in individuals with Noonan syndrome. J Clin Endocrinol Metab. 2005;90(9):5377-81.
23. Sarkozy A, Conti E, Seripa D, Digilio MC, Grifone N, Tandoi C, et al. Correlation between PTPN11 gene mutations and congenital heart defects in Noonan and LEOPARD syndromes. J Med Genet. 2003;40(9):704-8.

24. Denayer E, Devriendt K, de RavelT, Van Buggenhout G, Smeets E, Francois I, et al. Tumor spectrum in children with Noonan syndrome and SOS1 or RAF1 mutations. Genes Chromosomes Cancer. 2010;49(3):242-52.

25. Roberts $A E$, Araki T, Swanson KD, Montgomery KT, Schiripo TA, Joshi VA, et al. Germline gain-of-function mutations in SOS1 cause Noonan syndrome. Nat Genet. 2007;39(1):70-4.

26. Alfieri P, Cesarini L, Zampino G, Pantaleoni F, Selicorni A, Salerni A, et al. Visual function in Noonan and LEOPARD syndrome. Neuropediatrics. 2008;39(6):335-40.

27. Bertola DR, Pereira AC, Albano LM, De Oliveira PS, Kim CA, Krieger JE. PTPN11 gene analysis in 74 Brazilian patients with Noonan syndrome or Noonan-like phenotype. Genet Test. 2006 Fall;10(3):186-91.

28. Tanner JM, Whitehouse RH, Takaishi M. Standards from birth to maturity for height, weight, height velocity, and weight velocity: British children, 1965. I. Arch Dis Child. 1966;41(219):454-71.

29. Ranke MB, Heidemann $P$, Knupfer $C$, Enders $H$, Schmaltz AA, Bierich JR. Noonan syndrome: growth and clinical manifestations in 144 cases. Eur J Pediatr. 1988;148(3):220-7.

30. Ferreira LV, Souza SA, Montenegro LR, Arnhold IJ, Pasqualini T, Heinrich JJ, et al. [Phenotype variability in Noonan syndrome patients with and without PTPN11 mutation]. Arq Bras Endocrinol Metabol. 2007;51(3):450-6.

31. Bertola DR, Pereira AC, Passetti F, de Oliveira PS, Messiaen L, Gelb BD, et al. Neurofibromatosis-Noonan syndrome: molecular evidence of the concurrence of both disorders in a patient. Am J Med Genet A. 2005;136(3):242-5.

32. Thiel $C$, Wilken M, Zenker M, Sticht $H$, Fahsold R, Gusek-Schneider GC, et al. Independent NF1 and PTPN11 mutations in a family with neurofibromatosis-Noonan syndrome. Am J Med Genet A. 2009;149A(6):1263-7. 